\title{
Inorganic phosphate nanorods are a novel fluorescent label in cell biology
}

\author{
Chitta Ranjan Patra, Resham Bhattacharya, Sujata Patra, Sujit Basu, \\ Priyabrata Mukherjee and Debabrata Mukhopadhyay*
}

\author{
Address: Department of Biochemistry and Molecular Biology, Mayo Clinic Cancer Center, Mayo Clinic, Rochester, Minnesota, USA \\ Email: Chitta Ranjan Patra - patra.chittaranjan@mayo.edu; Resham Bhattacharya - bhattacharya.resham@mayo.edu; \\ Sujata Patra - patra.sujata@mayo.edu; Sujit Basu - basu.sujit@mayo.edu; Priyabrata Mukherjee - mukherjee.priyabrata@mayo.edu; \\ Debabrata Mukhopadhyay* - mukhopadhyay.debabrata@mayo.edu \\ * Corresponding author
}

Published: 30 October 2006

Journal of Nanobiotechnology 2006, 4:II doi:10.1I86/1477-3155-4-II
Received: 28 July 2006

Accepted: 30 October 2006

This article is available from: http://www.jnanobiotechnology.com/content/4/I/II

(C) 2006 Patra et al; licensee BioMed Central Ltd.

This is an Open Access article distributed under the terms of the Creative Commons Attribution License (http://creativecommons.org/licenses/by/2.0), which permits unrestricted use, distribution, and reproduction in any medium, provided the original work is properly cited.

\begin{abstract}
We report the first use of inorganic fluorescent lanthanide (europium and terbium) ortho phosphate $\left[\mathrm{LnPO}_{4} \cdot \mathrm{H}_{2} \mathrm{O}, \mathrm{Ln}=\mathrm{Eu}\right.$ and $\left.\mathrm{Tb}\right]$ nanorods as a novel fluorescent label in cell biology. These nanorods, synthesized by the microwave technique, retain their fluorescent properties after internalization into human umbilical vein endothelial cells (HUVEC), 786-O cells, or renal carcinoma cells (RCC). The cellular internalization of these nanorods and their fluorescence properties were characterized by fluorescence spectroscopy (FS), differential interference contrast (DIC) microscopy, confocal microscopy, and transmission electron microscopy (TEM). At concentrations up to $50 \mu \mathrm{g} / \mathrm{ml}$, the use of $\left[{ }^{3} \mathrm{H}\right]$-thymidine incorporation assays, apoptosis assays (TUNEL), and trypan blue exclusion illustrated the non-toxic nature of these nanorods, a major advantage over traditional organic dyes
\end{abstract}

\section{Background}

Nanotechnology, the creation of new objects in nanoscale dimensions, is a cutting edge technology having important applications in modern biomedical research [1-7]. Because the dimension of nanoscale devices is similar to cellular components such as DNA and proteins $[8,9]$, tools developed through nanotechnology may be utilized to detect or monitor several diseases at the molecular level $[3,10,11]$. Bio-imaging with inorganic fluorescent nanorods probes have recently attracted widespread interest in biology and medicine [1-4,12-14] compared to nanospheres. According to the reported literature [15], there is a drastic reduction of the plasmon dephasing rate in nanorods compared to small nanospheres due to a suppression of interband damping [15]. These rods show very little radiation damping due to their small volumes. These findings imply large local-field enhancement factors and relatively high light-scattering efficiencies, making metal nanorods extremely interesting for optical applications. Therefore, we are highly interested to examine the possibility of using inorganic fluorescent nanorods, especially lanthanide ortho phosphate $\mathrm{LnPO}_{4} \cdot \mathrm{H}_{2} \mathrm{O}$ [ $\mathrm{Ln}=\mathrm{Eu}$ or Tb], as fluorescent labels in cell biology. On the otherhand, in comparison to organic dyes (including Fluorescein, Texas $\operatorname{Red}^{\mathrm{Tm}}$, Lissamine Rhodamine $\mathrm{B}$, and Tetramethylrhodamine) and fluorescent proteins (Green fluorescent protein, GFP), inorganic fluorescent nanoparticles have several unique optical and electronic properties including sizeand composition-tunable emission from visible to infrared wavelengths, a large stokes shift, symmetric emission 
spectrum, large absorption coefficients across a wide spectral range, simultaneous excitation of multiple fluorescent colors, very high levels of brightness, [4,13], high resistance to photobleaching, and an exceptional resistance to photo- and chemical degradation [2-5,13,16,17] ].

Bio-conjugated inorganic nanoparticles have raised new possibilities for the ultrasensitive and multiplexed imaging of molecular targets in living cells, animal models, and possibly in human subjects. In this context, lanthanidebased inorganic fluorescents, especially Eu- and Tb-phosphate nanoparticles, have attracted a great deal of attention in cell biology. Optical properties of europium (Eu) and terbium (Tb) salts and their chelates have been used in diverse biomedical applications, namely time-resolved fluorometric assays and immunoassays [18-26]. Furthermore, there are some previous reports regarding the introduction of inorganic luminescent nanospheres such as $\mathrm{CdSe}, \mathrm{ZnS}, \mathrm{PbSe}$, ZnSe, and ZnS into cells [4,27,28]; however, these compounds are toxic to the cells. As the potential toxic effects of nanomaterials (nanospheres or nanorods) is a topic of considerable importance, the in vivo toxicity of Eu and $\mathrm{Tb}$ salts will be a key factor in determining whether the fluorescent imaging lanthanide probes could be used in vivo. In our study, lanthanide phosphate $\left[\mathrm{LnPO}_{4} \cdot \mathrm{H}_{2} \mathrm{O}\right.$, where $\mathrm{Ln}=\mathrm{Eu}$ and $\left.\mathrm{Tb}\right]$ nanorods were found to be non-toxic to endothelial cells as analyzed by cell proliferation assays [29] and the TUNEL assay. Moreover, to the best of our knowledge, there is no known report internalization of naked (nanorods without surface modifications of peptides, organic molecules, or polymers) fluorescent nanorods $\left(\mathrm{EuPO}_{4} \cdot \mathrm{H}_{2} \mathrm{O}\right.$ and $\mathrm{TbPO}_{4} \cdot \mathrm{H}_{2} \mathrm{O}$ ) into cells. In order to functionalize the surface of nanorods, we used aminopropyl trimethoxy silane (APTMS) or mercapto-propyl trimethoxy silane (MPTMS) as reported in the literature [30]. The functionalization of these nanorods using the microwave technique [30] is currently ongoing in our laboratory.

To the best of our knowledge, this is the first report of inorganic lanthanide phosphate fluorescent nanorods as fluorescent labels in cell biology. In the present study, $\mathrm{EuPO}_{4} \cdot \mathrm{H}_{2} \mathrm{O}$ and $\mathrm{TbPO}_{4} \cdot \mathrm{H}_{2} \mathrm{O}$ nanorods have been prepared by microwave heating and characterized as described previously [31]. The microwave technique is simple, fast, clean, efficient, economical, non-toxic, and eco-friendly [31]. The aim of our study was to investigate whether these inorganic fluorescent nanorods were capable of entering the cells and retaining their fluorescent properties for detection post-internalization. If so, drugs or biomolecules attached to these nanorods can then be detected after internalization and benefit future imaging, therapeutics, and diagnostic purposes. The aim of this paper is not to compare the toxicity of inorganic fluorescent nanorods with other inorganic fluorescent nanopar- ticles such as CdSe or CdTe but to explore and find new inorganic fluorescent materials that can be used as fluorescent labels in cell biology.

\section{Results and discussion}

The morphologies of $\mathrm{LnPO}_{4} \cdot \mathrm{H}_{2} \mathrm{O}$ [ $\mathrm{Ln}=\mathrm{Eu}$ and $\left.\mathrm{Tb}\right]$ nanomaterials were further characterized by transmission electron microscopy (TEM) at different magnifications (Figure 1A-D). The TEM images of as-synthesized products clearly showed that $\mathrm{EuPO}_{4} \cdot \mathrm{H}_{2} \mathrm{O}$ material (Figure $1 \mathrm{~A}-$ B) entirely consists of nanorods [6 to $8 \mathrm{~nm}$ in diameter and 100 to $300 \mathrm{~nm}$ in length] and $\mathrm{TbPO}_{4} \cdot \mathrm{H}_{2} \mathrm{O}$ products (Figure $1 \mathrm{C}-\mathrm{D}$ ) were a mixture of two rod types in micrometer size (small rods at 0.5 to $1.5 \mu \mathrm{m}$ in length and 6 to 8 $\mathrm{nm}$ in width and bigger rods at 1.1 to $2.2 \mu \mathrm{m}$ in length and 80 to $130 \mathrm{~nm}$ in width).

The excitation and emission spectra of $\mathrm{LnPO}_{4} \cdot \mathrm{H}_{2} \mathrm{O}$ are shown in Fig. 2A-D. The main emission peaks (Fig. 2B) for $\mathrm{EuPO}_{4} \cdot \mathrm{H}_{2} \mathrm{O}$ were observed at $588 \mathrm{~nm}, 615 \mathrm{~nm}$, and $695 \mathrm{~nm}$ after excitation at $393 \mathrm{~nm}$ (Fig. 2A). Similarly, the main emission peaks (Fig. 2D) for $\mathrm{TbPO}_{4} \cdot \mathrm{H}_{2} \mathrm{O}$ were observed at $490 \mathrm{~nm}, 543 \mathrm{~nm}$ (major), and $588 \mathrm{~nm}$ after excitation at $378 \mathrm{~nm}$ (Fig. 2C). The other excitation wavelengths for $\mathrm{EuPO}_{4} \cdot \mathrm{H}_{2} \mathrm{O}$ were $415 \mathrm{~nm}, 444 \mathrm{~nm}, 464 \mathrm{~nm}$, $488 \mathrm{~nm}$ (week), $525 \mathrm{~nm}, 535 \mathrm{~nm}$ etc (data not shown). Excitation wavelengths for $\mathrm{TbPO}_{4} \cdot \mathrm{H}_{2} \mathrm{O}$ were $283 \mathrm{~nm}$, 302 nm, 317 nm, 340 nm, 350 nm, 367 nm, 460 nm, 488 nm etc (all are not shown here). Excitation at any of these wavelengths resulted in similar emission spectra (data not shown) for $\mathrm{EuPO}_{4} \cdot \mathrm{H}_{2} \mathrm{O}$ and $\mathrm{TbPO}_{4} \cdot \mathrm{H}_{2} \mathrm{O}$. The excitation spectrum of $\mathrm{Eu}^{3+}$ (Fig. 2A) and $\mathrm{Tb}^{3+}$ (Fig. 2C) revealed an intense band at $393 \mathrm{~nm}$ and at $283 \mathrm{~nm}$ (due to the $\mathrm{f}-\mathrm{f}$ transitions), respectively. The emission spectrum (Fig. 2B) was composed of a ${ }^{5} \mathrm{D}_{0^{-7}} \mathrm{~F}_{\mathrm{J}}(\mathrm{J}=1,2,3,4)$ manifold of emission lines of $\mathrm{Eu}^{3+}$ with the magnetic-dipole allowed ${ }^{5} \mathrm{D}_{0}{ }^{-7} \mathrm{~F}_{1}$ transition ( $588 \mathrm{~nm}$ ) being the most prominent emission lines. TbPO ${ }_{4} \cdot \mathrm{H}_{2} \mathrm{O}$ yielded the characteristic blue ${ }^{5} \mathrm{D}_{4}-{ }^{7} \mathrm{~F}_{\mathrm{J}^{\prime}}$ $\left(\mathrm{J}^{\prime}=4,5\right)$ emission and the green ${ }^{5} \mathrm{D}_{3}{ }^{-7} \mathrm{~F}_{\mathrm{J}}(\mathrm{J}=3,4,5,6)$ emission of $\mathrm{Tb}^{3+}$ though the ${ }^{5} \mathrm{D}_{4}^{-7} \mathrm{~F}_{5}(543 \mathrm{~nm})$ green emission was the most prominent band (Fig. 2D). Such fluorescence properties of inorganic nanorods $\left(\mathrm{LnPO}_{4} \cdot \mathrm{H}_{2} \mathrm{O}\right)$ have attracted a great deal of attention in biology because they have a strong optical emission that exhibits a sharper spectral peak than typical organic dyes, have a large Stokes shift, and are minimally influenced by other chemicals. The emission spectrum has the following salient characteristics: (i) large Stokes shift $(615-393=222$ or 543-283 $=260$ dependent upon the emission wavelength of europium excitation at $393 \mathrm{~nm}$ or terbium excitation at 283 $\mathrm{nm}$ ), (ii) a narrow and symmetric emission at $615 \mathrm{~nm}$ for europium and $543 \mathrm{~nm}$ for terbium, and (iii) a long-lasting existence. Therefore, our nanorods, despite its slightly larger size, satisfy all the criteria of inorganic fluorescent nanoparticles. 


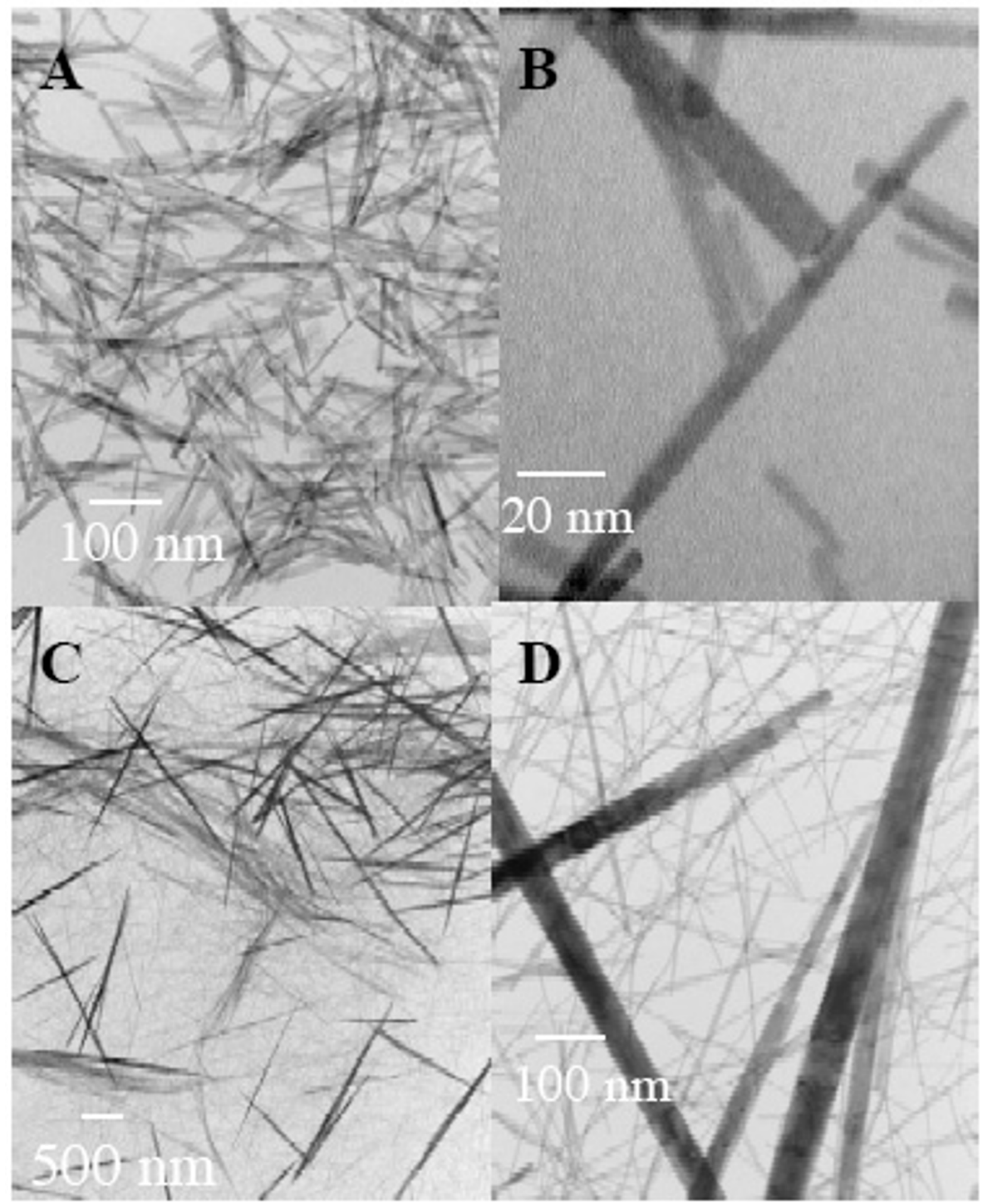

Figure I

TEM images of as-synthesized (A-B) EuPO ${ }_{4} \cdot \mathrm{H}_{2} \mathrm{O}$ nanorods and (C-D) TbPO${ }_{4} \cdot \mathrm{H}_{2} \mathrm{O}$ nanorods with different magnifications, respectively. 

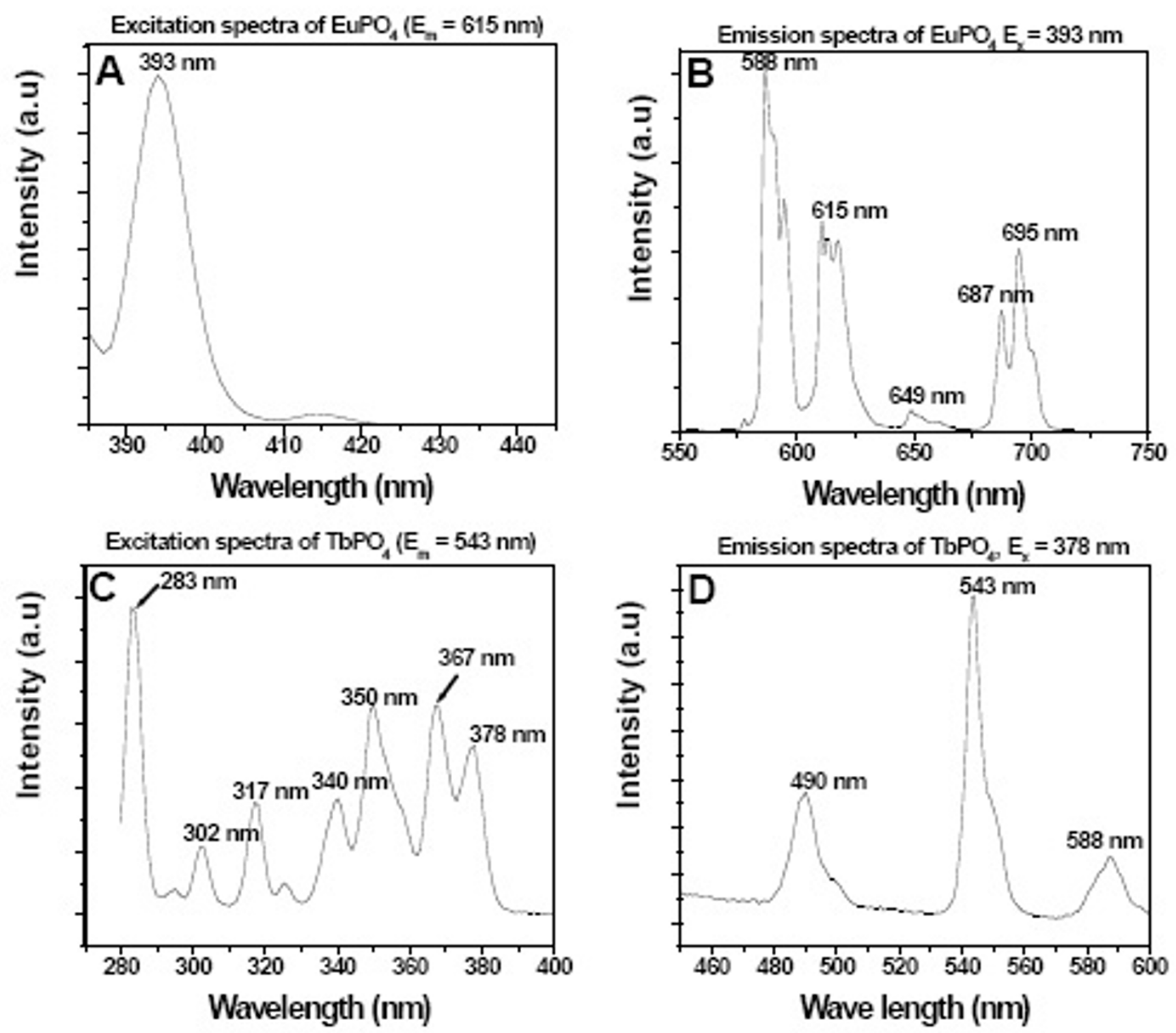

Figure 2

Excitation (A,C) and emission spectra (B,D) of as-synthesized EuPO ${ }_{4} \cdot \mathrm{H}_{2} \mathrm{O}, \mathrm{TbPO}_{4} \cdot \mathrm{H}_{2} \mathrm{O}$ nanorods.

In order to determine if the fluorescence activity of these $\mathrm{LnPO}_{4} \cdot \mathrm{H}_{2} \mathrm{O}$ nanorods remain unchanged inside the cell, $786-\mathrm{O}$ cells and HUVEC are incubated for 24 hours with these nanorods at various concentrations and the emission (fluorescence) spectra were recorded on a Fluorolog3 Spectrofluorometer after extensive washing with PBS (phosphate buffer saline) and shown in Figure 3A-B. Figure $3 \mathrm{~A}$ shows the emission spectra of 786-O cells loaded with $\mathrm{EuPO}_{4} \cdot \mathrm{H}_{2} \mathrm{O}$ nanorods at different concentrations: 0 $\mu \mathrm{g} / \mathrm{ml}$ (curve-a), $50 \mu \mathrm{g} / \mathrm{ml}$ (curve-b), and $100 \mu \mathrm{g} / \mathrm{ml}$ (curve-c), respectively. Similarly, Figure 3B shows the emission spectra of HUVEC cells loaded with $\mathrm{TbPO}_{4} \cdot \mathrm{H}_{2} \mathrm{O}$ nanorods at different concentrations: $0 \mu \mathrm{g} /$ $\mathrm{ml}$ (curve-a), $20 \mu \mathrm{g} / \mathrm{ml}$ (curve-b), $50 \mu \mathrm{g} / \mathrm{ml}$ (curve-c), and $100 \mu \mathrm{g} / \mathrm{ml}$ (curve-d), respectively. Similar results were obtained when 786-O cells were treated with $\mathrm{TbPO}_{4} \cdot \mathrm{H}_{2} \mathrm{O}$ and HUVEC cells were treated with $\mathrm{EuPO}_{4} \cdot \mathrm{H}_{2} \mathrm{O}$ nanorods (data not shown). It was observed that with increasing concentrations of $\mathrm{LnPO}_{4} \cdot \mathrm{H}_{2} \mathrm{O}$ nanorods $(0$ to $100 \mu \mathrm{g} /$ $\mathrm{ml}$ ), the rate of nanorod accumulation inside the 786-O and HUVEC cells increased as the fluorescence intensity from curve -a to curve $-\mathrm{c} / \mathrm{d}$ increased (Figure 3A-B). As these nanorods show their distinct fluorescence properties inside the HUVEC and 786-O cells, it indirectly proves that these nanorods are internalized (which is confirmed by TEM, as discussed later). 

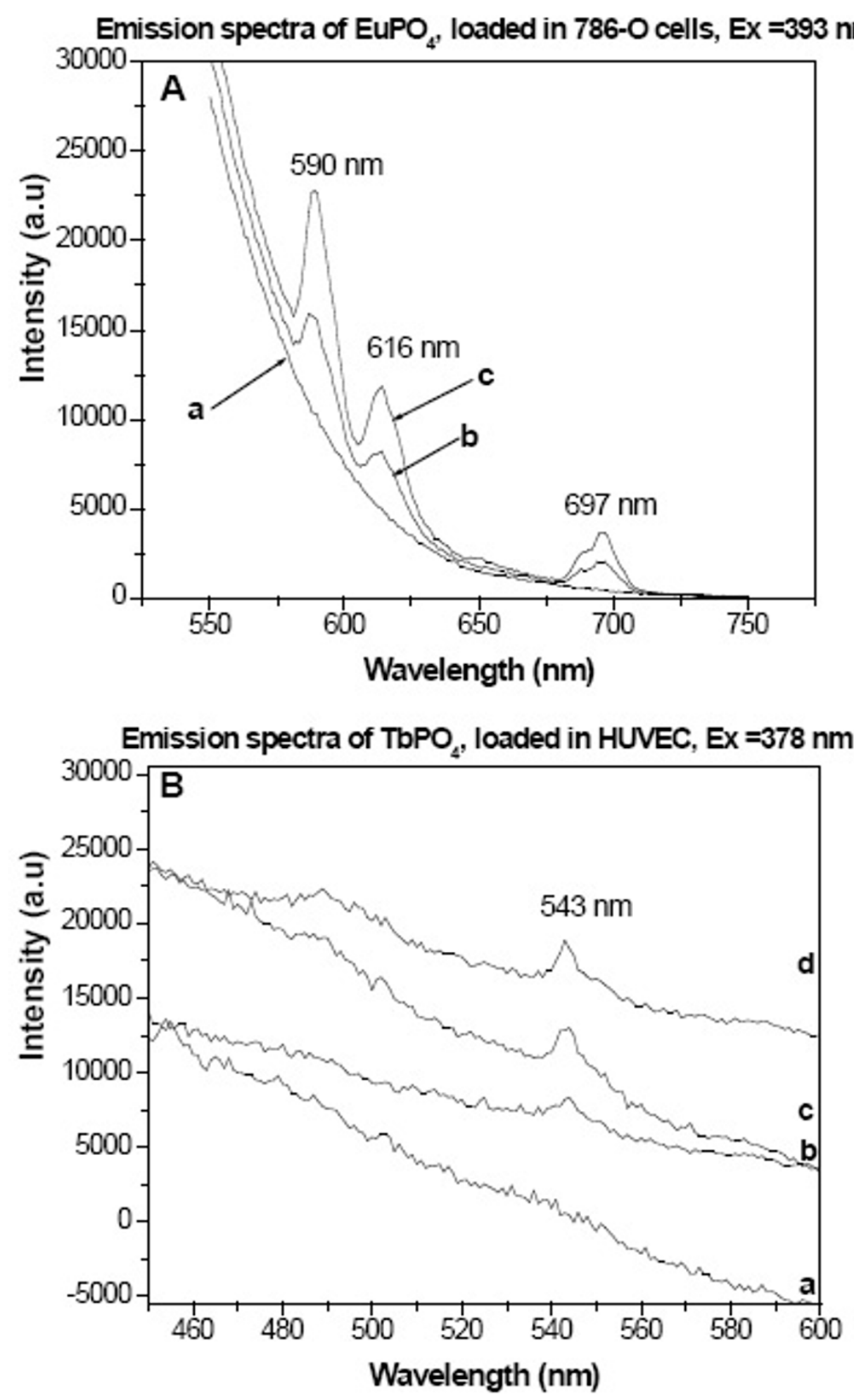

Figure 3

Emission spectra of $(\mathrm{A}) \mathrm{EuPO}_{4} \cdot \mathrm{H}_{2} \mathrm{O}$ nanorods loaded inside 786-O cells treated at various concentrations $(\mathrm{a}=0 \mu \mathrm{g} / \mathrm{ml}, \mathrm{b}=50$ $\mu \mathrm{g} / \mathrm{ml}, \mathrm{c}=100 \mu \mathrm{g} / \mathrm{ml}),(\mathrm{B}) \mathrm{TbPO}_{4} \cdot \mathrm{H}_{2} \mathrm{O}$ nanorods loaded inside HUVEC cells treated at various concentrations $(\mathrm{a}=0 \mu \mathrm{g} / \mathrm{ml}, \mathrm{b}$ $=20 \mu \mathrm{g} / \mathrm{ml}, \mathrm{c}=50 \mu \mathrm{g} / \mathrm{ml}, \mathrm{d}=100 \mu \mathrm{g} / \mathrm{ml})$. 
A number of methods such as differential interference contrast (DIC) microscopy, confocal microscopy and transmission electron microscopy (TEM) has been used to determine cellular trajectories of nanorods and are described below. Differential interference contrast (DIC) microscopy pictures of HUVEC (Fig. 4A-F) clearly show a significant difference in contrast between the untreated control cells (Fig. 4A), the cells treated with $\mathrm{EuPO}_{4} \cdot \mathrm{H}_{2} \mathrm{O}$ (Fig. 4B-D), and the cells treated with $\mathrm{TbPO}_{4} \cdot \mathrm{H}_{2} \mathrm{O}$ nanorods (Fig. 4E-F) at various concentrations. Similar results were obtained when 7886-O cells were treated with $\mathrm{LnPO}_{4} \cdot \mathrm{H}_{2} \mathrm{O}$ nanorods (data not shown). These results again indirectly prove that these $\mathrm{LnPO}_{4} \cdot \mathrm{H}_{2} \mathrm{O}$ nanorods are internalized.

Inorganic fluorescent $\mathrm{EuPO}_{4} \cdot \mathrm{H}_{2} \mathrm{O}$ and $\mathrm{TbPO}_{4} \cdot \mathrm{H}_{2} \mathrm{O}$ nanorods inside the 786-O cells (Fig. 5) and HUVEC (data not shown here) were detected by confocal microscopy. The fluorescence (left column) and their corresponding

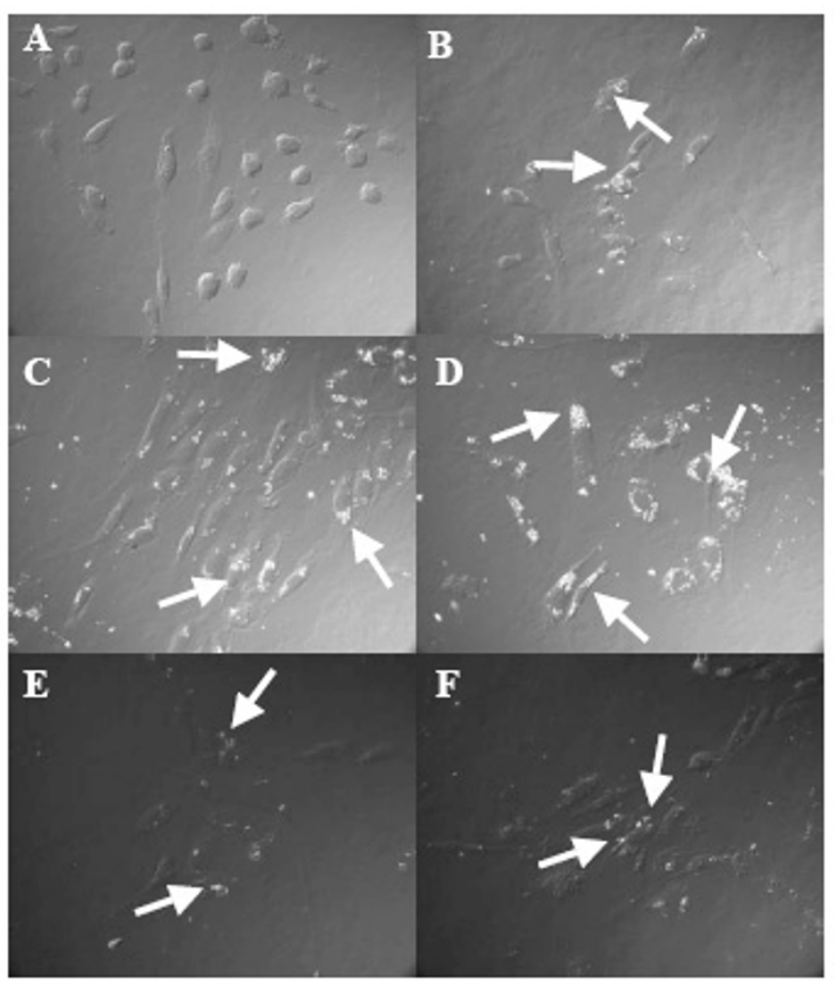

\section{Figure 4}

DIC microscopy pictures of HUVEC with nanorods and without nanorods. A: control HUVEC with no treatment, no nanorods were observed, (B-D): HUVEC treated with EuPO $_{4} \cdot \mathrm{H}_{2} \mathrm{O}$ at different concentrations (B: $20 \mu \mathrm{g} / \mathrm{ml}, \mathrm{C}: 50$ $\mu \mathrm{g} / \mathrm{ml}$ and $\mathrm{D}: 100 \mu \mathrm{g} / \mathrm{ml})$, and $(\mathrm{E}-\mathrm{F})$ : HUVEC treated with $\mathrm{TbPO}_{4} \cdot \mathrm{H}_{2} \mathrm{O}$ nanorods at different concentrations (E: $50 \mu \mathrm{g} /$ $\mathrm{ml}$ and $\mathrm{F}: 100 \mu \mathrm{g} / \mathrm{ml})$. In few places, nanorods, inside the cells, were marked by white arrow sign (B-D). phase images of untreated control cells (Fig. 5A), cells treated with $\mathrm{EuPO}_{4} \cdot \mathrm{H}_{2} \mathrm{O}$ nanorods (Fig. 5B), and cells treated with $\mathrm{TbPO}_{4} \cdot \mathrm{H}_{2} \mathrm{O}$ nanorods (Fig. 5C) were shown. The EuPO ${ }_{4} \cdot \mathrm{H}_{2} \mathrm{O}$ nanorods have a useful excitation region from 250 to $535 \mathrm{~nm}$ with a maximum at $393 \mathrm{~nm}$ [26]. In this study, confocal fluorescence microscopy images and phase images of cells were collected through the use of a Zeiss LSM 510 confocal laser scan microscope with a CApochromat 63 X/NA 1.2 water-immersion lens in conjunction with an Argon ion laser (488 nm excitation). The fluorescence emission was collected with a $100 \mathrm{X}$ microscope objective then spectrally filtered using a $515 \mathrm{~nm}$ long pass filter. Analysis by confocal laser scanning microscopy (excitation at $\lambda=488 \mathrm{~nm}$ ) shows the presence of green fluorescent structures scattered in the cytoplasmic compartments of cells treated with nanorods (Fig. 5B-C). It was also observed that there were very few green fluorophores (Fig. 5A) inside the cells due to auto-fluorescence whereas in Fig. 5(B-C), fluorophores were clearly observed due to the presence of $\mathrm{Eu}^{3+}$ and $\mathrm{Tb}^{3+}$ ions in crystallized $\mathrm{LnPO}_{4} \cdot \mathrm{H}_{2} \mathrm{O}$ nanorods. Overall, there is a significant difference in fluorescence between untreated control cells (Fig. 5A) and nanorods treated cells (Fig. 5B-C). These results prove the internalization of $\mathrm{LnPO}_{4} \cdot \mathrm{H}_{2} \mathrm{O}$ nanorods inside 786-O cells. Similar results were obtained when HUVEC were treated with $\mathrm{LnPO}_{4} \cdot \mathrm{H}_{2} \mathrm{O}$ nanorods (data not shown). On the otherhand, a red emission was expected from cells treated with $\mathrm{EuPO}_{4} \cdot \mathrm{H}_{2} \mathrm{O}$ nanorods. Unfortunately, we could not distinguish the huge fluorescence intensity between untreated control cells and nanorod-treated cells when we collected the emission spectra in red region. Therefore, we have collected the emission spectra for $\mathrm{EuPO}_{4} \cdot \mathrm{H}_{2} \mathrm{O}$ loaded cells in the green emission region (515 nm long pass filter). However, the confocal experiments for best fluorescence images are currently under detailed investigations in our laboratory.

Excitation and emission spectra of $\mathrm{EuPO}_{4} \cdot \mathrm{H}_{2} \mathrm{O}$ and $\mathrm{TbPO}_{4} \cdot \mathrm{H}_{2} \mathrm{O}$ nanorods were detected at the recommended wavelength by a spectrofluorometer, indicating that properties of the nanorods remained unchanged upon internalization into cells (Fig. 3A-B). However, for confocal microscopy, the same recommended excitation wavelengths were not available on the instrument. Thus, we took confocal images after excitation at $488 \mathrm{~nm}$ and collected emission with a $515 \mathrm{~nm}$ long pass filter. We found that after excitation at $488 \mathrm{~nm}$ and collected the emission spectrum with a $515 \mathrm{~nm}$ long pass filter, there was a significant and clear distinction between the fluorescence intensity of untreated cells (Fig. 5A) and nanorodtreated cells (Fig. 5-C). However, after scanning through a number of different excitation wavelengths as reported in the literature [26], we could not clearly distinguish between the fluorescence intensity of untreated cells and 


\section{6-O Cell}

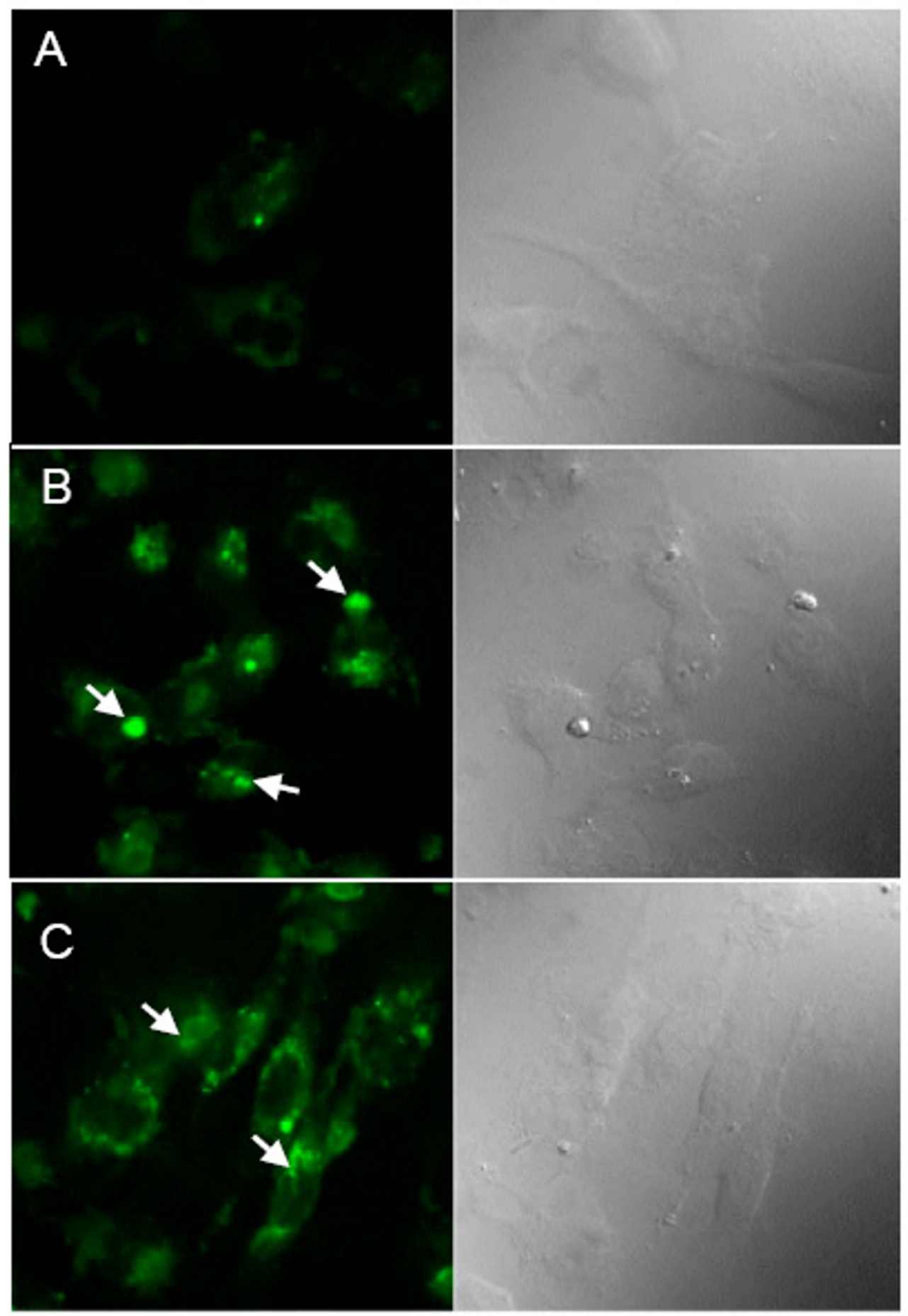

\section{Figure 5}

Fluoresence (First column) and their corresponding phase images (Second column) of 786-O cells treated with $\mathrm{LnPO}_{4} \cdot \mathrm{H}_{2} \mathrm{O}$ nanorods. (A): Control 786-O cells with no treatment, slight green color due to auto fluorescence in (A), (B): 786-O cells treated with EuPO $\mathrm{HP}_{4} \cdot \mathrm{H}_{2} \mathrm{O}$ nanorods, and $(\mathrm{C})$ : 786-O cells treated with $\mathrm{TbPO}_{4} \cdot \mathrm{H}_{2} \mathrm{O}$ nanorods, taken by confocal microscope. In few places green fluorescence color of nanorods inside the cells, were marked by white arrow sign. 
nanorod-treated cells. Because this is our first report using inorganic lanthanide phosphates $\left(\mathrm{EuPO}_{4} \cdot \mathrm{H}_{2} \mathrm{O}\right.$ and $\mathrm{TbPO}_{4} \cdot \mathrm{H}_{2} \mathrm{O}$ ) as a fluorescent biological label, there is no evidence to show that an emission is detectable with a 515 $\mathrm{nm}$ long pass filter. However, it was reported in the literature that a $488 \mathrm{~nm}$ excitation wavelength [26] was used in confocal microscopy to detect luminescent properties of europium (III) nanoparticles.

The TEM image of 786-O cells treated with $\mathrm{EuPO}_{4} \cdot \mathrm{H}_{2} \mathrm{O}$ nanorods was shown in Fig. 6. This figure clearly indicated that in most of the cells, uptake of these nanorods occurred. Fig. 7A-C and Fig. 7D-F represent the TEM images of HUVEC cells treated with $\mathrm{EuPO}_{4} \cdot \mathrm{H}_{2} \mathrm{O}$ nanorods and with $\mathrm{TbPO}_{4} \cdot \mathrm{H}_{2} \mathrm{O}$ nanorods, respectively, illustrating that both nanorods could enter the cytoplasmic compartments. The morphology of these cells also clearly demonstrated that they were healthy after internalizing these materials (Fig. 6 and Fig. 7) though their spherical shape was due to trypsinization, neutralization with TNS, and fixation in Trumps solution for TEM. Similarly, the morphology of the fluorescent nanorods remained unchanged after internalization. Similar results were obtained when the 786-O cells were treated with $\mathrm{LnPO}_{4} \cdot \mathrm{H}_{2} \mathrm{O}$ nanorods (data not shown). From the combination of Fig. 1D and Fig. 7F, it appears that the small rods seen in Figure $1 \mathrm{D}$ were not internalized by the endothelial cells as illustrated with TEM (Fig. 7F). However, other than the larger $\mathrm{TbPO}_{4} \cdot \mathrm{H}_{2} \mathrm{O}$ nanorods, some aggregated rods were visible in the cytoplasm. It is possible that these smaller rods aggregate similar to cadmiumbased salts [32] but are notably less toxic when taken up by endothelial cells.

Considering our results from fluorescence spectroscopy, DIC, confocal, and TEM, we've shown that these fluorescent nanorods can be internalized in a cellular system and are readily visualized by microscopy. These nanorods then offer a useful alternative as fluorescent probes for targeting various molecules to specific cells. The exact mechanism for internalization of these nanorods still remains unclear but is under investigation in our laboratory.

Since these inorganic nanorods show distinct fluorescence activity upon cellular internalization, we have decided to use these materials as a fluorescent label for HUVEC and 786-O cells. We examined their in vitro toxicity with $\left[{ }^{3} \mathrm{H}\right]-$ thymidine incorporation assays [29] on normal endothelial cells (HUVEC) and found them to be non-toxic (Fig. $8 \mathrm{~A}-\mathrm{B})$. Although there were indications that exposure to certain nanomaterials might lead to adverse biological effects, this appears to dependent upon the chemical and physical properties of the material $[4,27,28]$. The potential toxicity of inorganic fluorescent nanoparticles has recently become a topic of considerable importance and discussion, especially since in vivo toxicity is likely to be a key factor in determining whether fluorescent probes will be approved by regulatory agencies for human clinical use. HUVEC proliferation [29] was clearly not affected from internalization of materials up to $50 \mathrm{mg} / \mathrm{ml}$ compared to control samples (Fig. 8A-B); however, at concentrations greater than $50 \mathrm{mg} / \mathrm{ml}$, nanorods were detected to be toxic. Experiments were repeated in triplicate and results were reproducible.

To observe viability, HUVEC were treated with $50 \mu \mathrm{g} / \mathrm{ml}$ of europium and terbium phosphate nanorods for 24-48 hours. There was no difference in cell death between untreated control cells (no treatment) and nanorodtreated cells as assessed by trypan blue (data not shown). These results illustrate a biocompatibility between the nanorods and the cells.

To investigate whether uptake of these nanorods induce apoptosis, we assayed endothelial cells treated with LnPO4.H2O nanorods using two apoptotic methods: (i) fluorescence microscopy using the In Situ Cell Death Detection Kit, TMR red (Roche, Cat. No.\#12 156792 910) and (ii) flow cytometry using Annexin V-FITC Apoptosis Detection Kit (Biovision, Cat. No. K101-100). The TUNEL assay detects apoptosis-induced DNA fragmentation through a quantitative fluorescence assay and was performed according to the manufacturer's instructions. In tunnel assay, the positive control apoptosis has been induced in cells using camptothecin $(\sim 2.5 \mathrm{mM})$ for $4 \mathrm{~h}$ of incubation (Fig. 9(A-A2)). The red-colored (TMR redstained nuclei) apoptotic cells (Fig. 9A) were visualized under a microscope, counted ( 6 fields per sample), and photographed using a digital fluorescence camera. The DAPI-stained nuclei appeared blue in Fig. 9.A1 and Fig. 9.A2 shows the merged images of TMR- and DAPI-stained cells. The results of the TUNEL assay for the untreated control HUVEC and HUVEC cells treated with $\mathrm{LnPO}_{4} \cdot \mathrm{H}_{2} \mathrm{O}$ nanorods are shown in Fig. 9B-D. In the first column (BD) of Figure 9, no nuclei of TMR red-stained HUVEC cells were detected due to the absence of apoptotic cells. Blue DAPI-stained nuclei are in the second column (B1-D1) and the third column (B2-D2) shows the merged images. There was no difference in the number of apoptotic cells ( $\sim 0 \%$ ) detected in the untreated control experiment (First row: B, B1 and B2) nor cells treated with $\mathrm{EuPO}_{4} \cdot \mathrm{H}_{2} \mathrm{O}$ nanorods (second row: C, C1 and C2) and $\mathrm{TbPO}_{4} \cdot \mathrm{H}_{2} \mathrm{O}$ nanorods (third row: D, D1 and D2). The results of Fig. 6 and Fig. 9 clearly indicate that these nanorods were not toxic to endothelial cells. Similarly, flow cytometry analysis yielded no difference in the number of apoptotic cells bewteen untreated controls and nanoparticle-treated (data not shown). 


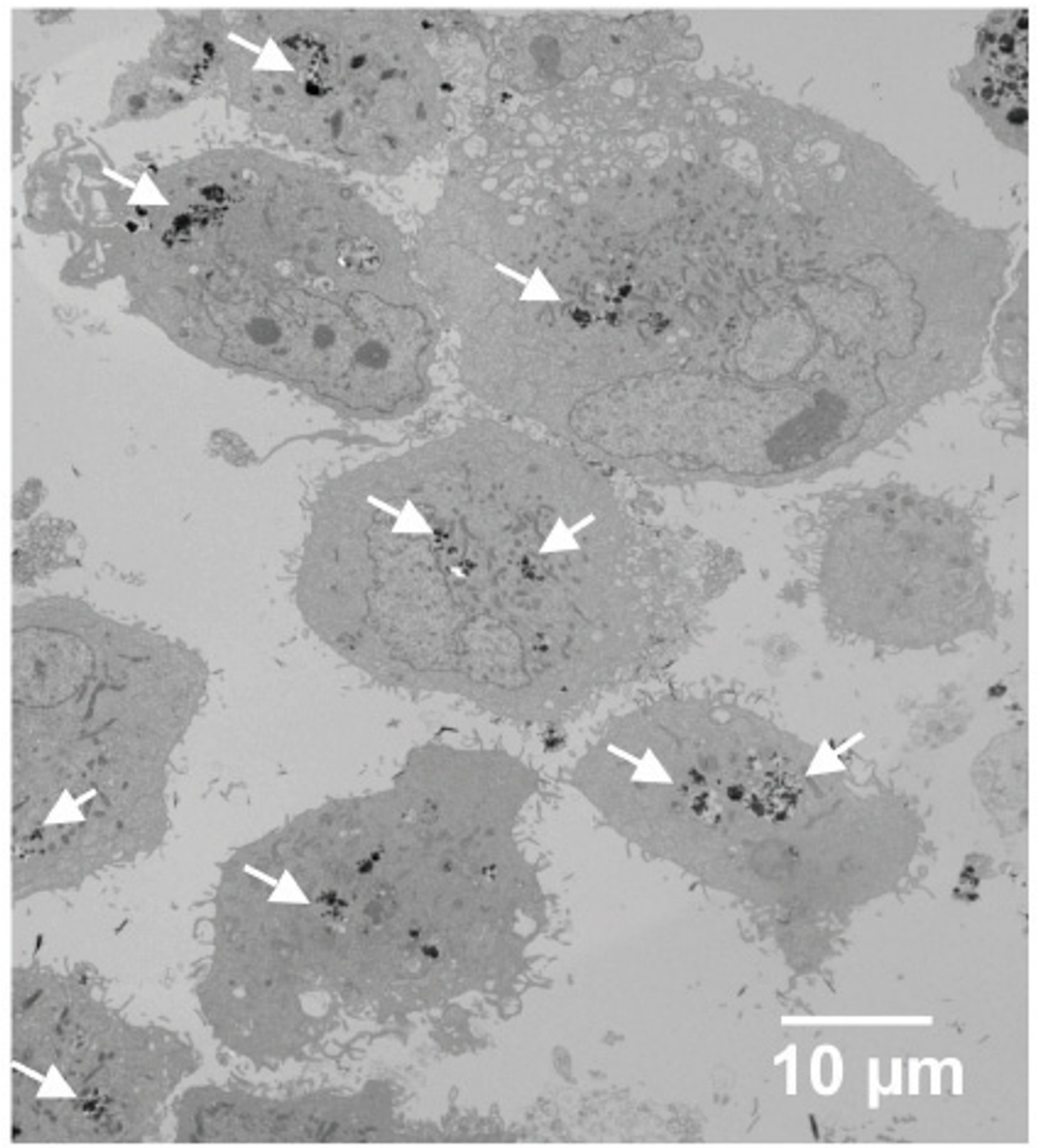

\section{Figure 6}

EuPO $_{4} \cdot \mathrm{H}_{2} \mathrm{O}$ fluorescent nanorods, were visualized by TEM inside the cytopplasmic compartments of 786-O cells. In few places, $\mathrm{EuPO}_{4} \cdot \mathrm{H}_{2} \mathrm{O}$ nanorods, inside the cells, are marked by white arrow signs. 

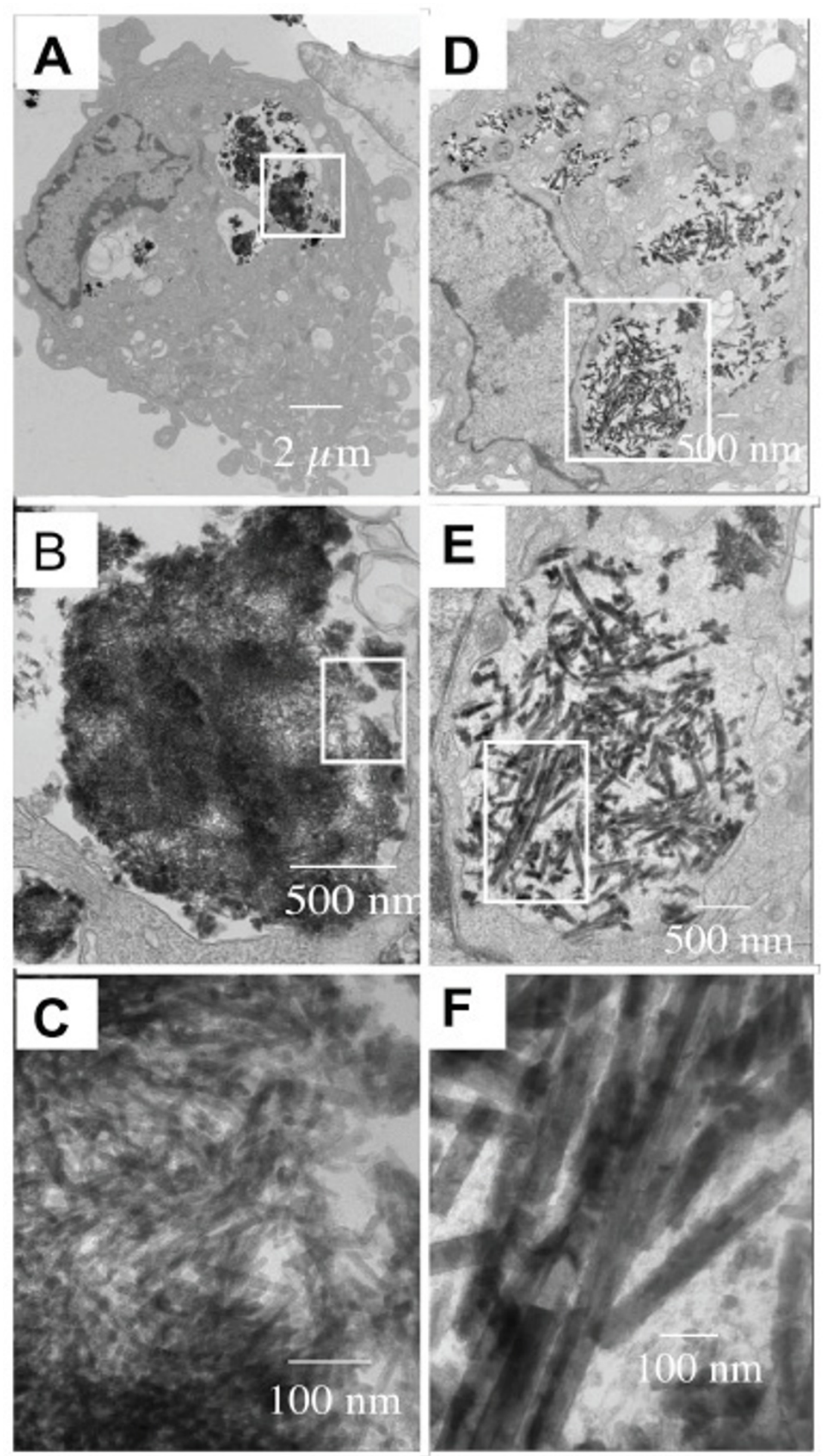

\section{Figure 7}

Fluorescent $\mathrm{LnPO}_{4} \cdot \mathrm{H}_{2} \mathrm{O}$ nanorods were visualized by TEM inside the cytoplasmic compartments of HUVEC. (A-C) EuPO $_{4} \cdot \mathrm{H}_{2} \mathrm{O}$ nanorods and (D-F) $\mathrm{TbPO}_{4} \cdot \mathrm{H}_{2} \mathrm{O}$ nanorodsare observed inside the HUVEC with increasing magnifications. $B$ was the enlarge picture of white block in $A, C$ was the enlarge picture of white block in B. Similarly, E was the enlarge picture of white block in $D$ and $F$ was the enlarge picture of white block in $E$. 

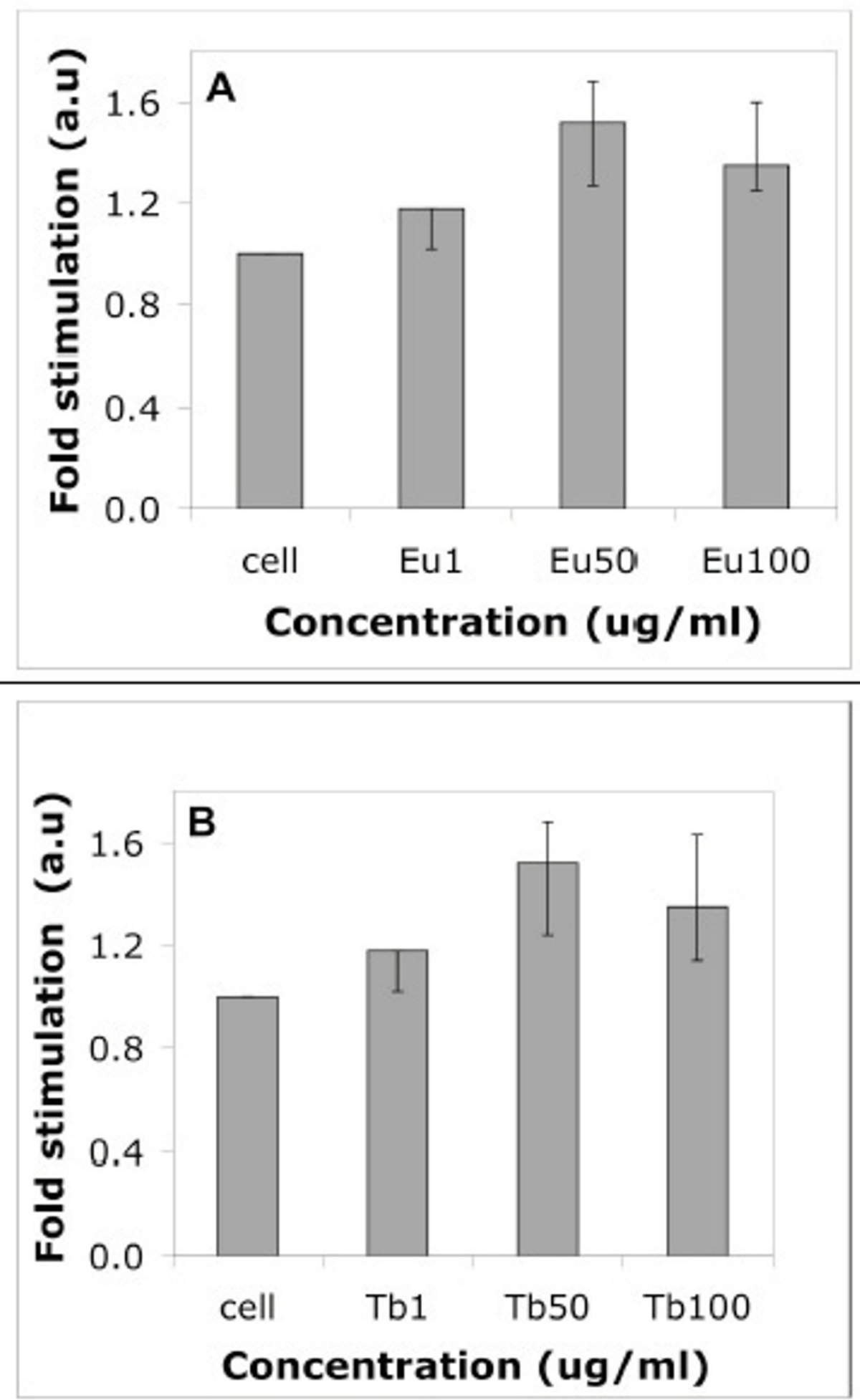

Figure 8

Effect of fluorescent nanorods $\left(\mathrm{EuPO}_{4}\right.$ and $\left.\mathrm{TbPO}_{4}\right)$ with different concentrations to normal $\mathrm{HUVEC}$ was observed by $\left[{ }^{3} \mathrm{H}\right]$ thymidine incorporation asssay. A serum-starved $\mathrm{HUVEC}$ was treated with $(\mathrm{A}) \mathrm{EuPO}_{4} \cdot \mathrm{H}_{2} \mathrm{O}$ nanorods and $(\mathrm{B}) \mathrm{TbPO}_{4} \cdot \mathrm{H}_{2} \mathrm{O}$ nanorods at the concentration range of $\mathrm{I}-100 \mu \mathrm{g} / \mathrm{mL}[\mathrm{Eu} I=I \mu \mathrm{g} / \mathrm{ml}$, Eu50 $=50 \mu \mathrm{g} / \mathrm{ml}$, Eu I00 $=100 \mu \mathrm{g} / \mathrm{ml}$. Similarly, TbI $=\mathrm{I} \mu \mathrm{g} / \mathrm{ml}$, $\mathrm{Tb} 50=50 \mu \mathrm{g} / \mathrm{ml}$, Tbl00 $=100 \mu \mathrm{g} / \mathrm{ml}$. Average of three independent experiments, each was done in triplicate. 


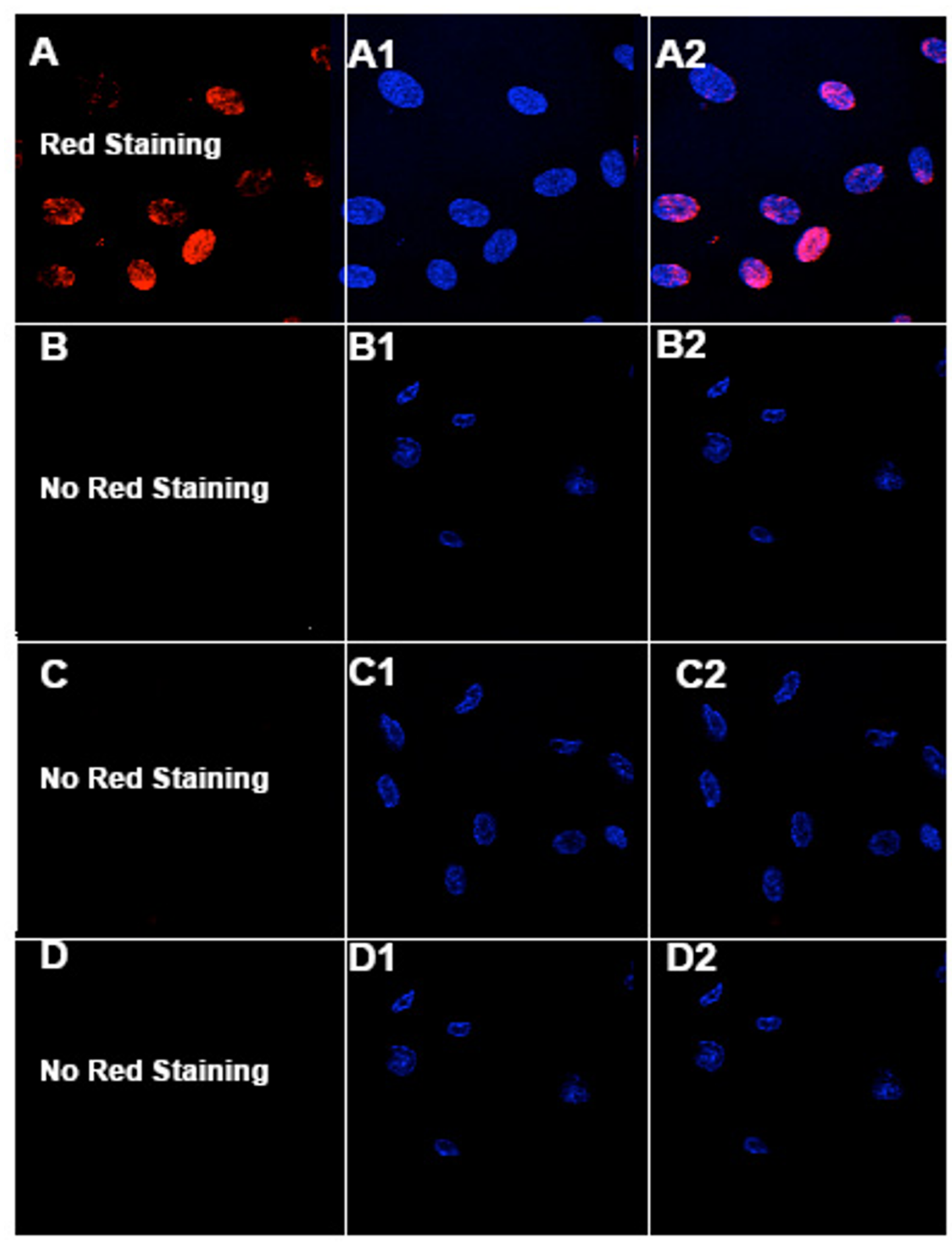

\section{Figure 9}

TUNEL assay apoptosis of HUVEC. First row: positive control experiment, second row: untreated control experiment, third row: HUVEC treated with EuPO $\mathrm{H}_{2} \mathrm{O}$ at $50 \mu \mathrm{g} / \mathrm{ml}$ for $20 \mathrm{~h}$ of incubation at $37^{\circ} \mathrm{C}$ and fourth row: HUVEC treated with $\mathrm{TbPO}_{4} \cdot \mathrm{H}_{2} \mathrm{O}$ at $50 \mu \mathrm{g} / \mathrm{ml}$ for $24 \mathrm{~h}$ of incubation at $37^{\circ} \mathrm{C}$. TUNEL assay apoptosis of HUVEC using camptothecin (4 h incubation at $37^{\circ} \mathrm{C}$ ) as positive inducer (First row). A: TMR red -stained nuclei of HUVEc appear in red color due to presence of apoptotic cells, AI: The DAPI-stained nuclei appear in blue and A2: merged picture of A and AI. First Column: The nuclei of HUVEC were stained with TMR red (B-D), red staining was not observed due to absence of no apoptotic cells. Second column: The DAPI-stained nuclei appear in blue (BI-DI), and Third column: merged picture of first and second column (B2-D2). 
Parak et al. [32] has indicated that the cellular toxicity of stable nanomaterials is primarily due to aggregation rather than the release of Cd elements. However, in our case, since these nanorods are based on an entirely different material than cadmium, their mechanism is likely to be different than Cd-based materials. Therefore, if the toxicity of Cd-based materials is due to an aggregation of ion, that may not be the case for nanorods as supported by our data.

While there is no direct evidence for the effect of nanoparticle size on internalization and toxicity, some reports indicate that nanoparticle size is involved $[28,32,33]$. In our case, we are currently studying in detail the cytotoxicity and mechanism for the cellular internalization of these nanorods. Finally, we should mention in our experiments, the correct control would be a non-fluorescent lanthanide phosphate compound instead of untreated cells. We are currently working on the synthesis of such a reagent. Along with this work, we are also determining: (a) the mechanism of internalization; (b) the cytotoxicity of these materials; (c) the photostability and quantum efficiency of these materials; (d) the surface functionalization of these materials; (e) drug delivery using these nanorods after surface modifications; and (f) the comparison between the fluorescent and non-fluorescent lanthanide phosphate compounds in all experiments.

Nanorods are stable at room temperature indefinitely. We have performed chemical characterizations (XRD, TGA, DSC, TEM, fluorescence properties) on samples that are 4-5 months old and have detected no difference between freshly prepared nanorods and older samples including the absence of any agglomeration.

\section{Conclusion}

A novel alternative to conventional organic dyes, we have reported the use of inorganic fluorescent $\mathrm{EuPO}_{4} \cdot \mathrm{H}_{2} \mathrm{O}$ and $\mathrm{TbPO}_{4} \cdot \mathrm{H}_{2} \mathrm{O}$ as a fluorescent label in biomedical research. We have shown internalization of $\mathrm{EuPO}_{4} \cdot \mathrm{H}_{2} \mathrm{O}$ and $\mathrm{EuPO}_{4} \cdot \mathrm{H}_{2} \mathrm{O}$ nanorods by both $786-\mathrm{O}$ cells and HUVEC using fluorescence spectroscopy (FS), DIC, confocal microscopy, and TEM. The nanorods were observed to localize mainly in the cytoplasmic compartments of cells and did not appear to detrimentally affect cell viability nor induce any toxicity after internalization. These unique fluorescent nanorods offer new advancements in the detection and diagnosis for cancer therapy at an early stage and we are currently working on functionalizing these nanorods as well as utilizing them as specific vehicles for drug delivery.

\section{Experimental procedures Materials}

Europium (III) nitrate hydrate $\left[\mathrm{Eu}\left(\mathrm{NO}_{3}\right)_{3} \cdot \mathrm{xH}_{2} \mathrm{O}\right.$, 99.99\%], terbium (III) nitrate hexahydrate $\left[\mathrm{Tb}\left(\mathrm{NO}_{3}\right)_{3} \cdot 6 \mathrm{H}_{2} \mathrm{O}, 99.999 \%\right]$, ammonium dihydrogenphosphate, $\left[\mathrm{NH}_{4} \mathrm{H}_{2} \mathrm{PO}_{4} 99.999 \%\right]$, were purchased from Aldrich, USA. [ $\left.{ }^{3} \mathrm{H}\right]$-Thymidine was purchased from Amersham Biosciences, Piscataway, NJ. 786-O cells were purchased from American Type Culture Collection (ATCC, TIB-186, Rockville, MD). Dulbeco's Modification of Eagle's Medium (DMEM, 1X) was purchased from Cellgro, Mediatech, Inc, Herndon, VA, USA. Endothelial Cell Basal Medium (EBM), human umbilical vein endothelial cells (HUVEC) were obtained from Cambrex Bio Science alkersvile, Inc, MD, USA.

\section{Microwave-assisted synthesis of lanthanide ortho phosphate hydrates $\left(\mathrm{LnPO}_{4} \cdot \mathrm{H}_{2} \mathrm{O}\right)$}

The inorganic fluorescent nanoparticles $\left(\mathrm{LnPO}_{4} \cdot \mathrm{H}_{2} \mathrm{O}\right)$ were synthesized using microwave techniques as reported in the literature [31]. In a typical synthesis, $20 \mathrm{ml} 0.05(\mathrm{M})$ of aqueous $\mathrm{NH}_{4} \mathrm{H}_{2} \mathrm{PO}_{4}$ were added to $20 \mathrm{ml} 0.05$ (M) of an aqueous solution of $\mathrm{Ln}\left(\mathrm{NO}_{3}\right)_{3}(\mathrm{Ln}=\mathrm{Eu}$ and $\mathrm{Tb})$ in a $100 \mathrm{ml}$ round-bottomed flask. The $\mathrm{pH}$ of the solution before and after the reaction was in the range of $1.8-2.2$. The sample was irradiated for 20 min with $50 \%$ of the instrument's power. The microwave refluxing apparatus was a modified domestic microwave oven (GOLD STARR $1000 \mathrm{~W}$ with a $2.45 \mathrm{GHz}$ ), described previously [34]. In the post-reaction treatment, the resulting products were collected, centrifuged at $36303 \mathrm{~g}\left(20,000 \mathrm{rpm}\right.$ with $\mathrm{r}_{\mathrm{av}}=$ $8.125 \mathrm{~cm}$ ), washed several times using ethanol and distilled water, and then dried overnight under vacuum at room temperature. The yield of the as-prepared products is more than $95 \%$.

\section{Cell culture experiments}

HUVEC and 786-O cells were cultured at $10^{5} \mathrm{cells} / 2 \mathrm{ml}$ in six well plates for $24 \mathrm{~h}$ at $37^{\circ} \mathrm{C}$ and $5 \% \mathrm{CO}_{2}$ in EBM and DMEM complete media. For investigating the cellular localization (using confocal microscope), cells were plated on glass cover slips and grown to $90 \%$ confluence, and then incubated with $\mathrm{LnPO}_{4} \cdot \mathrm{H}_{2} \mathrm{O}$ nanorods at a concentration of $50-100 \mu \mathrm{g} / \mathrm{ml}$. After $20 \mathrm{~h}$ of incubation, the cover slips were rinsed extensively with phosphate buffered saline (PBS) and cells were fixed with freshly prepared 4\% paraformaldehyde in PBS for $15 \mathrm{~min}$ at room temperature and then re-hydrated with PBS. Once all the cells were fixed, the cover slips were mounted onto glass slides with Fluor Save mounting media and examined with DIC and confocal microscopy. For detection of apoptosis using the TUNEL assay (Roche, USA, Cat. No. \# 12 156792 910), cells were mounted onto glass slides with mounting media containing DAPI (4'-6-Diamidino-2phenylindole). 
In another set of experiments, 786-O and HUVEC cells $\left(10^{5}\right.$ cells $\left./ 2 \mathrm{ml}\right)$ were cultured in six well plates and treated with $\mathrm{LnPO}_{4} \cdot \mathrm{H}_{2} \mathrm{O}$ nanorods in corresponding DMEM and EBM complete media without cover slips. After $20 \mathrm{~h}$ of incubation with the nanorods, the cells were washed with PBS, trypsinized, and neutralized. The cells were washed by centrifugation and re-suspended in PBS and analyzed with fluorescence spectroscopy, TEM, and flow cytometry (for detection of apoptosis of cells using annexin-FTIC-PI, Bio Vision, USA, catalog \# K101-100). Cell viability for another set of cells was determined through staining with trypan blue and cells were counted using a hemocytometer.

\section{Cell proliferation assay}

Cell proliferation to measure in vitro toxicity was performed with the $\left[{ }^{3} \mathrm{H}\right]$-thymidine incorporation assay according to the reported literature [29]. Briefly, endothelial cells (HUVEC; $2 \times 10^{4}$ ) were seeded in 24-well plates, cultured for 2 days in EBM, serum-starved (0.1\% serum) for 24 hours, and then treated with different concentrations $(1-100 \mu \mathrm{g} / \mathrm{mL})$ of $\mathrm{LnPO}_{4} \cdot \mathrm{H}_{2} \mathrm{O}(\mathrm{Ln}=\mathrm{Eu}$, Tb). After 20 hours, $1 \mu \mathrm{Ci}\left[{ }^{3} \mathrm{H}\right]$ thymidine was added to each well. Four hours later, cells were washed with cold PBS, fixed with $100 \%$ cold methanol, and collected for the measurement of trichloroacetic acid-precipitable radioactivity [29]. Experiments were repeated in triplicate and all results were reproducible.

\section{Apoptosis assay}

Cells were seeded into 6 -well plates at a density of $2 \times 10^{5}$ $/ 2 \mathrm{ml}$ of medium per well and grown overnight. After appropriate treatment with these nanorods $(50 \mu \mathrm{g} / \mathrm{mL})$, cells were extensively washed with PBS and tested with the Annexin V-FITC Apoptosis Detection Kit (Biovision, Cat. No. \#K101-100) per the manufacturer's instructions. In addition, apoptosis was also determined by the TUNEL assay using the In Situ Cell Death Detection Kit, TMR red (Roche, Cat. No. \#12 156792 910). The red apoptotic cells were visualized on a microscope, counted ( 6 fields per sample), and photographed using a digital fluoresence camera.

\section{Characterization techniques Transmission electron microscopy study}

Particle morphology (microstructures of the samples) was studied with TEM on a FEI Technai 12 operating at $80 \mathrm{KV}$. To visualize the internalization of particles inside the cells, we have folllowed the published literature procedures [35,36].

\section{Fluorescence microscopy}

The excitation and emission (fluorescence) spectra were recorded on a Fluorolog-3 Spectrofluorometer (HORIBA
JOBINYVON, Longjumeau, France) equipped with a xenon lamp as the monochromator excitation source.

\section{Differential interference contrast microscopy (DIC)}

After fixation of cells on cover slips, the cells were mounted onto glass slides with Fluor Save mounting media and examined for DIC. Pictures were captured with AXIOCAM high-resolution digital camera using an AXIOVERT 135 TV microscope (ZEISS, Germany).

\section{Confocal fluorescence microscopy}

Two dimensional confocal fluorescence microscopy images were collected through use of LSM 510 confocal laser scan microscope (Carl Zeiss, Inc., Oberkochcn, Germany) with C-Apochromat $63 \mathrm{X} / \mathrm{NA} 1.2$ water-immersion lense, in conjunction with an Argon ion laser (488 nm excitation). The fluorescence emissions were collected through a $515 \mathrm{~nm}$ long pass filter.

After mounting the cells onto glass slides with DAPI, images were collected through a LSM 510 confocal laser scan microscope (Carl Zeiss, Inc., Oberkochcn, Germany) with a C-Apochromat $63 \mathrm{X} / 1.2$ na water-immersion lens. The fluorescence emissions were collected through a 385$470 \mathrm{~nm}$ band pass filter in conjunction with an argon ion laser excitation of $364 \mathrm{~nm}$ for DAPI. The fluorescence emissions were collected through a 560-615 nm band pass filter in conjunction with a HeNe1 ion laser excitation of $543 \mathrm{~nm}$ for TMR red.

\section{Authors' contributions}

CRP conceived the study and did the experiments and data analysis. SP coordinated some cell culture experiments. RB, SB, and PM also conceived the study and participated in its design and coordination and helped to draft the manuscript. DM provided guidance with the experimental design and manuscript preparation. All authors read and approved the final manuscript.

\section{Acknowledgements}

We are thankful to Drs. William Wessels, Franklyn Prendergast, Sutapa Sinha, Kaustubh Datta, Michael Muders, and Enfeng Wang for their scientific help and discussion. We are also thankful to J. Tarara and J. Charlesworth for their help with the confocal and transmission electron microscopy, respectively. This work was partly supported by $\mathrm{NIH}$ grants CA78383 and HL70567 and also a grant from the American Cancer Society to D. Mukhopadhyay.

\section{References}

I. Bruchez M, Moronne M, Gin P, Weiss S, Alivisatos PA: Semiconductor Nanocrystals as fluorescent biological labels. Science 1998, 281:2013-2016.

2. Alivisatos PA: The use of nanocrystals in biological detection. Nature Biotechhnology. Nature Biotechnology 2004, 2:47-52.

3. Medintz IL, Uyeda HT, Goldman I ER, Mattoussi H: Quantum dot bioconjugates for imaging, labelling and sensing. Nat Mat 2005, 4:435-446. 
4. Gao X, Yang L, Petros JA, Marshall FF, Simons JW, Nie S: In vivo molecular and cellular imaging with quantum dots. Curr Opin Biotechnol 2005, 16:63-72.

5. Parak WJ, Gerion D, Pellegrino T, Zanchet D, Micheel C, Williams CS, Boudreau R, Le Gros MA, Larabell CA, Alivisatos PA: Biological applications of colloidal nanocrystals. Nanotechnology 2003, I4:RI5-R27.

6. Jain KK: Nanotechnology in clinical laboratory diagnostics. Clinica Chimica Acta 2005, 358:37-54.

7. Salata OV: Applications of nanoparticles in biology and medicine. J Nanobiotechnology 2004, 2:3. doi: 10.1 I86/I477-3 I55-2-3

8. Thrall JH: Nanotechnology and Medicine. Radiology 2004 230:315-318.

9. Prescher JA, Bertozzi CR: Chemistry in living systems. Nature Chemical bilogy 2005, I:| 3-2I.

10. El-Sayed IH, Huang X, El-Sayed MA: Surface Plasmon Resonance Scattering and Absorption of anti-EGFR Antibody Conjugated Gold Nanoparticles in Cancer Diagnostics: Applications in Oral Cancer. Nano Lett 2005, 5:829-834.

II. Dubertret B, Calame M, Libchaber A: Single-mismatch detection using gold-quenched fluorescent oligonucleotides. Nature biotechnology 200I, 19:365-370.

12. Voura EB, Jaiswal JK, Mattoussi H, Simon SM: Tracking metastatic tumor cell extravasation with quantum dot nanocrystals and fluorescence emission-scanning microscopy. Nat Med 2004, 10:993-998.

13. Gao X, Cui Y, Levenson RM, Chung LW, Nie S: In vivocancer targeting and imaging with semiconductor quantum dots nology. Nature Biotechnol 2004, 22:969-976.

14. Michalet X, Pinaud FF, Bentolila LA, Tsay JM, Doose S, Li SS, Sundaresan G, Wu AM, Gambhir SS, Weiss S: Quantum Dots for Live Cells, in Vivo Imaging, and Diagnostics. Science 2005, 307:538-544.

15. Sönnichsen C, Franzl T, Wilk T, Plessen VG, Feldmann J, Wilson O, Mulvaney P: Drastic Reduction of Plasmon Damping in GoldNanorods. Phys Rev Lett 2002, 88:077402. [4 pages]

16. Murphy C): Optical sensing with quantum dots. Anal Chem 2002, 74:520A-526A.

17. Niemeyer CM: Nanoparticles, proteins, and nucleic acids: biotechnology meets materials science. Angew Chem Int Edn Eng 200I, 40:4128-4I58

18. Junhua Y, Parker D, Pal R, Poole RA, Cann MJ: A Europium Complex that Selectively Stains Nucleoli of Cells. JACS 2006, I 28:2294-2299.

19. Lim MJ, Patton WF, Lopez MF, Spofford KH, Shojaee N, Shepro D: A luminescent europium complex for the sensitive detection of proteins and nucleic acids immobilized on membrane supports. Anal Biochem 1997, 245: I84- 195.

20. Yuan JL, Wang G, Majima K, Matsumoto K: Synthesis of a Terbium Fluorescent Chelate and Its Application to Time-Resolved Fluoroimmunoassay. Anal Chem 200I, 73:1869-1876.

21. Scorilas A, Bjartell A, Lilja H, Moller C, Diamandis EP: StreptavidinPolyvinylamine Conjugates Labeled with a Europium Chelate: Applications in Immunoassay, Immunohistochemistry, and Microarrays. Clinic Chem 2000, 46:1450-I 455.

22. Qin QP, Lovgren T, Pettersson K: Development of Highly Fluorescent Detection Reagents for the Construction of Ultrasensitive Immunoassays. Anal Chem 2001, 73:152I-1529.

23. Ye Z, Tan M, Wang G, Yuan J: Novel fluorescent europium chelate-doped silica nanoparticles: preparation, characterization and time-resolved fluorometric application. J Mater Chem 2004, I 4:85I-856.

24. Hai X, Tan M, Wang G, Ye Z, Yuan J, Matsumoto K: Preparation and a Time-Resolved Fluoroimmunoassay Application of New Europium Fluorescent Nanoparticles. Anal Sci 2004, 20:245.

25. Nichkova M, Dosev D, Gee SJ, Hammock BD, Kennedy IM: Microarray Immunoassay for Phenoxybenzoic Acid Using Polymer Encapsulated Eu:Gd2O3 Nanoparticles as Fluorescent Labels. Anal Chem 2005, 77:6864-6873.

26. Nichkova M, Dosev D, Perron R, Gee SJ, Hammock BD, Kennedy IM: Eu 3+-doped Gd 203 nanoparticles as reporters for optical detection and visualization of antibodies patterned by microcontact printing. Anal Bioanal Chem 2006, 384:63I-637.
27. Jaiswal JK, Mattoussi H, Mauro JM, Simon SM: Long-term multiple color imaging of live cells using quantum dot bioconjugates. Nature Biotechnol 2002, 21:47-5I.

28. Derfus AM, Chan WCW, Bhatia SN: Probing the Cytotoxicity of Semiconductor Quantum Dots. Nano Lett 2004, 4: I I-I8.

29. Basu S, Nagy JA, Pal S, Vasile E, Eckelhoefer IA, Bliss VS, Manseau EJ, Dasgupta PS, Dvorak HF, Mukhopadhyay D: The neurotransmitter dopamine inhibits angiogenesis induced by vascular permeability factor/vascular endothelial growthfactor. Nat Med 200I, 7:569-574.

30. Feng J, Shan G, Maquieira A, Koivunen ME, Guo B, Hammock BD, Kennedy IM: Functionalized europium oxide nanoparticles used as a fluorescent label in an immunoassay for atrazine. Anal Chem 2003, 75:5282-5286.

31. Patra CR, Alexandra G, Patra S, Jacob DS, Gedanken A, Landau A Gofer Y: Microwave approach for the synthesis of rhabdophane-type lanthanide orthophosphate $(\mathrm{Ln}=\mathrm{La}, \mathrm{Ce}, \mathrm{Nd}$, $\mathrm{Sm}, \mathrm{Eu}, \mathrm{Gd}$ and $\mathrm{Tb}$ ) nanorods under solvothermal conditions. New J Chem 2005, 29:733-739.

32. Kirchner C, Liedl T, Kudera S, Pellegrino T, Javier AM, Gaub HE, StolIzle S, Fertig N, Parak WJ: Cytotoxicity of Colloidal CdSe and CdSe/ZnS Nanoparticles. Nano Lett 2005, 5:33I-338.

33. Xu ZP, Zeng QH, Lu GQ, Yu AB: Inorganic nanoparticles as carriers for efficient cellular delivery. Chemical Engineering Science 2006, $61: 1027-1040$.

34. Matsumura Inoue T, Tanabe M, Minami T, Ohashi T: A remarkably rapid synthesis of ruthenium(II) polypyridine complexes by microwave irradiation. Chemistry Letters 1994, 23:2443.

35. McDowell EM, Trump BF: Histologic fixatives suitable for. diagnostic light and electron microscopy. Arch Path Lab Med 1976, 10:405-4|4

36. Spurr AR: A low viscosity epoxy resin embedding medium for electron microscopy. Journal of Ultrastructure Research 1969 , 26:3I-36.
Publish with Bio Med Central and every scientist can read your work free of charge

"BioMed Central will be the most significant development for disseminating the results of biomedical research in our lifetime. "

Sir Paul Nurse, Cancer Research UK

Your research papers will be:

- available free of charge to the entire biomedical community

- peer reviewed and published immediately upon acceptance

- cited in PubMed and archived on PubMed Central

- yours - you keep the copyright

Submit your manuscript here:

http://www.biomedcentral.com/info/publishing_adv.asp
BioMedcentral 